Volume 57

Issue 3 Volume 57, Issue 3 (Fall 2020)

Special Issue: Law in the Time of COVID

Article 2

$1-19-2021$

\title{
COVID-19: Cost-Benefit Analysis and Politics
}

Dan Priel

Osgoode Hall Law School of York University

Follow this and additional works at: https://digitalcommons.osgoode.yorku.ca/ohlj

Part of the Law Commons

Article

\section{Citation Information}

Priel, Dan. "COVID-19: Cost-Benefit Analysis and Politics." Osgoode Hall Law Journal 57.3 (2021) : 537-565.

https://digitalcommons.osgoode.yorku.ca/ohlj/vol57/iss3/2

This Article is brought to you for free and open access by the Journals at Osgoode Digital Commons. It has been accepted for inclusion in Osgoode Hall Law Journal by an authorized editor of Osgoode Digital Commons. 


\title{
COVID-19: Cost-Benefit Analysis and Politics
}

\begin{abstract}
The COVID-19 pandemic forced governments around the world to make tough political decisions about the cost of saving lives and the limits of doing so. One of the striking aspects of the debates over these necessary tradeoffs is the relatively little weight individual rights seemed to have carried in these discussions. At first, this might have seen the triumph of cost-benefit analysis (CBA); and in a sense, it was. However, the pandemic has also shown the limitations of CBA, especially in the face of severe uncertainty. This essay reviews some of the sources of uncertainty in the context of the pandemic and shows how, in the face of such uncertainty, different countries fall back onto their political commitments, which include concern for individual rights. I thus argue that rather than being in competition to CBA, political considerations (including concern for individual rights) end up being incorporated into an impressionistic calculation of costs and benefits of government action. I conclude by suggesting that this is where future discussion of the theoretical foundations of CBA should focus on.
\end{abstract}




\section{COVID-19: Cost-Benefit Analysis and Politics}

\section{DAN PRIEL*}

The COVID-19 pandemic forced governments around the world to make tough political decisions about the cost of saving lives and the limits of doing so. One of the striking aspects of the debates over these necessary tradeoffs is the relatively little weight individual rights seemed to have carried in these discussions. At first, this might have seen the triumph of cost-benefit analysis (CBA); and in a sense, it was. However, the pandemic has also shown the limitations of CBA, especially in the face of severe uncertainty. This essay reviews some of the sources of uncertainty in the context of the pandemic and shows how, in the face of such uncertainty, different countries fall back onto their political commitments, which include concern for individual rights. I thus argue that rather than being in competition to CBA, political considerations (including concern for individual rights) end up being incorporated into an impressionistic calculation of costs and benefits of government action. I conclude by suggesting that this is where future discussion of the theoretical foundations of CBA should focus on.

I. IDEAS THAT TOOK A HIT .

II. THE TRIUMPH OF CBA? …

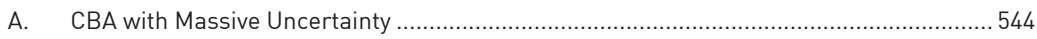

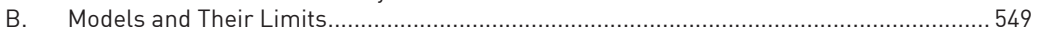

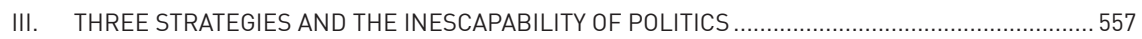

IV. WHERE DO WE GO FROM HERE: THE WELFARE STATE AND INFORMATION...........................5 562

Osgoode Hall Law School, York University. Thanks to Chad Flanders and to board members of the Osgoode Hall Law Journal for comments on a previous version of this article. 
OF ALL THAT HAS CHANGED following the outbreak of the COVID-19 pandemic, the one that most immediately affected people's lives is the stay-at-home orders that in different forms were put in place all over the world. While generally enjoying popular support, these policies also generated strong reactions from members of the public, politicians, policymakers, and scholars who worried that they were insufficiently thought through and may end up causing more harm than good. The worry boiled down to the view that the policies reflected a panicked response that failed to consider the potential costs of the lockdown policies. This article addresses this question. It is not an attempt to consider every aspect of these policies; it focuses only on the question of "tradeoffs"1 involved in them. As is clearer with every passing day, the isolation policies have saved many lives, but they also carry enormous costs, which will be felt for years to come. How, if at all, should these be weighed against each other?

Though the particular context in which this question is asked is as novel as the novel coronavirus, the question itself is not. It is arguably the most significant, most common, and probably also the most difficult, question that policy makers and lawyers face. For when we move from abstract legal principles to the real world of implementation and enforcement, where goals always outstrip budgets, the question is always "at the expense of what?" Other things being equal, a world with less crime, fewer accidents, cleaner environment, and healthier food than our own world is a better one. But other things are never equal. Achieving these goals does not come free; in fact, achieving improvements on some of the goals just mentioned may make it more difficult to improve on other goals we are also interested in (for example, greater equality and less poverty).

Many lawyers are often loath to think in these terms. Law, they say, is about justice, not efficiency; life is "priceless"; rights "are not for sale," and so the very attempt to talking in terms of numbers is seen as a kind of professional, or even moral, betrayal. ${ }^{2}$ But increasingly lawyers too acknowledge that governmental policies must involve some accounting for their downsides. Cost-Benefit Analysis (CBA) is a term used for a range of ideas and techniques on how to conduct this balancing. At its simplest, CBA is the view that public regulation of risk of harm should be based on an assessment of the expected harms and weighed against

1. See Emily Bazelon, "Restarting America Means People Will Die: So When Do We Do It?," The New York Times (10 April 2020), online: <nytimes.com/2020/04/10/ magazine/coronavirus-economy-debate.html>; $c f R v$ Michaud, 2015 ONCA 585 at paras 91-92 [Michaud].

2. For one book-length example of this attitude see Alain Supiot, Governance by Numbers: The Making of a Legal Model of Allegiance, translated by Saskia Brown (Hart, 2017). 
the costs of eliminating those risks. Risk-reducing actions should continue up to the point that the marginal cost of reducing the risk exceeds the expected gain from action.

This brief formulation may seem simple, and may strike some as obvious, but it remains controversial in theory and incredibly difficult to implement in practice. At the abstract level, some consider CBA an immoral approach that exhibits insufficient respect to human life and for everything else that is of real value. $^{3}$ Even setting aside such worries, trying to implement CBA raises a host of questions on what precisely should be weighed, who should do the weighing, how to measure certain losses and benefits, what weight (if any) should be given to distributive considerations, and many others.

The COVID-19 outbreak provides an opportunity to examine some of the questions surrounding CBA with a case study of governmental policies that affected billions of people the world over. In the context of the lockdown policies, CBA asks that we evaluate whether the costs of these policies in terms of the social and economic dislocation they cause are worth the benefits in terms of lives saved and other possible benefits. This may seem obvious as it is generally uncontroversial that given a certain budget, one should aim for the biggest bang for the buck. Likewise, given a limited choice between several courses of action (or inaction), it makes sense to opt for the (in)action that will minimize the losses and maximize the benefits. To use an analogy to a now-famous thought experiment, one may think of the budget as the railway in the trolley problem: It sets absolute limits on the decision maker's available options with a bad consequence occurring whichever option is taken. In such circumstances, most people think that one should choose the track that leads to fewer deaths. ${ }^{4}$ Similarly, CBA urges us to choose the least bad option.

But CBA is not quite analogical to the trolley problem, as it requires making judgments that many find counterintuitive and even outright immoral. For example, unlike the trolley problem that directly asks us to compare lives with lives, the costs and benefits involved with the lockdown policies are of different kinds. This requires creating some common currency to compare them. This in turn requires putting a price on life, and even less intuitively, implies that some

3. See Frank Ackerman \& Lisa Heinzerling, "Pricing the Priceless: Cost-Benefit Analysis of Environmental Protection" (2002) 150 U Pa L Rev 1553; Steven Kelman, "Cost-Benefit Analysis: An Ethical Critique," Reg (January-February 1981) 33.

4. See Marc D Hauser, Moral Minds: How Nature Designed Our Universal Sense of Right and Wrong (HarperCollins, 2006) at 127-28. 
lives may not be worth saving. Standard CBA thus denies that saving lives, and preventing harm, enjoys some lexical priority over other societal goals. ${ }^{5}$

These questions are significant for policymakers and lawyers, as many areas of law deal, directly or indirectly, with preventing harms. Increasingly, the law requires evaluating the costs involved in doing so in quite explicit terms. Regulatory policy guidelines published by the Canadian government's call for "evidence-based" rule making based on "robust analysis of costs and benefits, and the assessment of risk." 6 On a few occasions, Canadian courts have similarly acknowledged the need for some kind of balancing of costs against benefits, in both public and private law. ${ }^{7}$

Despite all this, CBA has received surprisingly little attention from Canadian legal academics. ${ }^{8}$ This short essay focuses on the different responses taken around

5. For a critique of CBA on these grounds see Gregory C Keating, "Principles of Risk Imposition and the Priority of Avoiding Harm” (2018) 36 Revus 1; see also Cass R Sunstein, The Cost-Benefit Revolution (MIT Press, 2018) at 27 (reporting on a survey showing that many disagree with CBA for related reasons).

6. Treasury Board of Canada Secretariat, "Cabinet Directive on Regulation," ss 3.0, 5.2.1, online: <canada.ca/en/treasury-board-secretariat/services/federal-regulatory-management/ guidelines-tools/cabinet-directive-regulation.html\#toc3>; see also Treasury Board of Canada Secretariat, Canada Cost-Benefit Analysis Guide: Regulatory Proposals (President of the Treasury Board, 2007) online (pdf): <tbs-sct.gc.ca/rtrap-parfa/analys/analys-eng.pdf>.

7. See e.g. Michaud, supra note 1 at para 95 ("The balancing of costs and benefits is in the very nature of regulatory design and its main challenge"). The question of judicial review of regulation for failure to meet $\mathrm{CBA}$ requirement received relatively little judicial attention in Canada. For one short discussion see Quebec (AG) v Canada (National Energy Board), [1994] 1 SCR 159 at 178-81. In private law, the need to balance costs against benefits has also been recognized in determining the standard of care in negligence. See Ryan v Victoria (City), [1999] 1 SCR 201 at para 28; cf Daborn v Bath Tramways Motor Co Ltd, [1946] 2 All ER 333 (CA) ("if all the trains in this country were restricted to a speed of five miles an hour, there would be fewer accidents, but our national life would be intolerably slowed down" at 336).

8. One rare exception, focused on environmental law, is Heather McLeod-Kilmurray \& Gavin Smith, "Unsustainable Development in Canada: Environmental Assessment, Cost-Benefit Analysis, and Environmental Justice in the Tar Sands" (2010) 21 J Envtl L \& Prac 65 at 83-91. The paucity of discussion is especially striking when compared with the interest in the topic by American legal academics. For an imprecise but instructive comparison, I searched Heinonline, the most comprehensive database of law journals, for articles with "cost-benefit analysis" in their title. Limiting the search to the United States yielded over 250 results. A similar search in Canadian publications yielded only two results (one from 1970, the other from 1986). (The article cited in this note comes from a journal that is not in the database.) Both were brief and did not touch on the foundational issues surrounding CBA. Even accounting for the difference in population size (and correspondingly the size of the legal academy), this is a significant difference. 
the world to the COVID-19 outbreak. As such, it cannot address many of the questions pertaining to CBA that have been canvassed in the vast literature surrounding it. Nevertheless, I hope it will spur interest beyond its particular subject matter on the need for a more open discussion of CBA in the Canadian regulatory context.

I begin this article by briefly considering some competitors to CBA that the pandemic has challenged. Of those, perhaps the most notable is how little weight individual rights seem to have had in discussions over the shutdown policies. Instead, discussion was dominated by attempts to evaluate the costs and benefits of different policies aimed at slowing the spread of the virus. While this may at first look like a victory for CBA, Part II argues that the pandemic also highlighted some serious difficulties with it, especially given the level of uncertainty against which decisions had to be made. Rather than CBA, different countries adopted one of several strategies, all acknowledging the need to balance costs against benefits but without any real attempt at a precise calculation. Part III describes three such strategies and argues that the choice of strategy was, partly at least, grounded in political ideas, including rights. Those could be incorporated within CBA (broadly conceived), but they also show the limits of this method. Finally, in Part IV, I draw some tentative conclusions about the longer-term implications of the pandemic and responses to it for future regulatory decision making in welfare states.

\section{IDEAS THAT TOOK A HIT}

I mentioned at the outset that the debate over the lockdown policies has been couched in the language of tradeoffs. That in itself is remarkable, because it means it was not couched in the language of rights. The lockdown policies constituted a direct, savage blow to an activity that only a few months ago everyone would have considered to be among our most basic rights: to wander around freely in the streets. Perhaps even more significant have been the severe restrictions imposed on people's use of their property, especially with respect to orders to shut down "non-essential" businesses. These policies, which were adopted with relatively little public protest, are a challenge to those who advance rights-based 
views of private law, where "the nub of a property right is that the owner rather than others gets to determine how the thing will be used."

It is not that the language of rights has been completely absent-there were definitely those who invoked it to object to various restrictions or requirements (like the wearing of protective masks) — but these voices were completely drowned out by the demand that we stay at home for the sake of the greater good, or, paternalistically, for individuals' own good. Those who invoked individual rights, which they claimed restricted government powers, were widely seen not as civil libertarian heroes but as selfish cranks. ${ }^{10}$ If rights operate as "trumps" of individual choice over general welfare, ${ }^{11}$ then the pandemic has not been a good time for rights.

It was not just right-wing notions of individual freedom that were hurt by the virus. Other non-consequentialist ideas voiced by more left-wing commentators were also afflicted. One is the idea of incommensurability, the view that goods or values of different kinds cannot be compared with each other. As each life is priceless, the protection of life must be outside any economic calculation. ${ }^{12}$ Another, related, idea is the lexical ordering of values, according to which the protection of life and the prevention of harm are prior to other lower-ranked values, and therefore cannot be traded off with them. In an essay entitled "Making Life Cheap," one commentator called CBA "straightforwardly eliminationist," and described it as follows:

Since the value of a human life can be quantified-at $\$ 9$ million to $\$ 10$ million, according to major federal agencies — death is acceptable, and lives expendable, when more valuable goods are involved. The coronavirus pandemic has breathed new life

9. Arthur Ripstein, "Possession and Use," in James Penner \& Henry E Smith, eds, Philosophical Foundations of Property Law (Oxford University Press, 2013) 156 at 160, 162 [emphasis in original]. Ripstein concedes (ibid at 160) that the right is subject to "public law limitations," but what he refers to does not include the limits imposed during the pandemic.

10. See e.g. Chris Herhalt, "Woman Roasted on Social Media after Refusing to Wear Mask in Toronto Hospital," CTV News (6 July 2020), online: <toronto.ctvnews. $\mathrm{ca} /$ woman-roasted-on-social-media-after-refusing-to-wear-mask-in-torontohospital-1.5012036>.

11. See Ronald Dworkin, A Matter of Principle (Harvard University Press, 1985) at 359. For an application of such ideas to pandemics see Janet E Mosher, "Accessing Justice amid Threats of Contagion" (2014) 51 Osgoode Hall LJ 919 (there need to be "clear and convincing evidence that [a] person whose rights are to be curtailed is infected with a contagious disease ... and poses a demonstrable threat to others" at 932).

12. See Ackerman \& Heinzerling, supra note 3 at 1562-63, 1564; Keating, supra note 5. 
into this old utilitarian chestnut, and it is precisely the life-reducing mindset of costbenefit analysis that has driven the resistance to social distancing. ${ }^{13}$

The overheated language cannot hide the weakness of the argument. No society has ever treated life as priceless (although by most measures human life is better protected today than at any time in history). ${ }^{14}$ And it is actually CBA that encourages various forms of social distancing as a cost-effective way of saving lives. ${ }^{15}$ It is also wrong to suggest that the pandemic has revived a dead idea, as CBA has been in use for decades, as it matches everyday moral practices that show that humans do not treat life as priceless. All human societies around the world permit, and often encourage, the private ownership and operation of motor vehicles, even though this results in a staggering, and entirely foreseeable, cost to life and limb. While it is an interesting question whether the private ownership of cars would have survived CBA, it is actually individual rights discourse that makes car ownership a matter of "personal choice" that is beyond government regulation. ${ }^{16}$

CBA of government risk regulation is a method that seeks to rationalize government action in order to achieve optimal risk reduction. CBA recognizes that all human activity — and what common-sense morality tends to forget, also human inactivity — carries with it the risk of injury and death. Even if societies decided to spend all their available funds on saving lives (something that no society has ever attempted), what specific actions should be taken to save most lives would remain an open question. And since opportunity costs are costs, even in such a scenario CBA would be inescapable. Therefore, properly understood, subjecting lockdown policies to CBA is not "a choice between lives and dollars." ${ }^{17}$ The dollars are used by people, and when they do not have them-when "the economy" falters-people are hurt. The contrast is based on a natural but fallacious tendency to weigh immediate outcomes that are the result of a direct causal path and ignore other outcomes whose causal paths are less obvious but no less real.

13. Aaron Timms, "Making Life Cheap," The New Republic (June 2020) 38 at 38, 40. The figures mentioned refer to value of a "statistical life," which is currently measured at about nine million USD. For a discussion see text accompanying note 39 below.

14. See generally Steven Pinker, The Better Angels of Our Nature: Why Violence Has Declined (Penguin, 2011) at chs 1-4.

15. See e.g. Chris Barrett et al, "Economic and Social Impact of Influenza Mitigation Strategies by Demographic Class" (2011) 3 Epidemics 19.

16. Cf Sarah A Seo, "The New Public" (2016) 125 Yale LJ 1616 at 1649-55 (recounting the characterization of driving as freedom from government intervention).

17. Timms, supra note 13 at 40 . 


\section{THE TRIUMPH OF CBA?}

\section{A. CBA WITH MASSIVE UNCERTAINTY}

Can we conclude from the preceding discussion, however truncated and brief, that the pandemic has finally shown that CBA is, as one commentator put it a few years ago, the "only game in town"? ${ }^{18}$ Alas, it turns out that matters are not quite so simple. While the idea behind CBA is sound, in practice CBA is valuable only if it rests on good data. Otherwise, it is potentially worse than useless, as it can create the impression of a precise numerical (and as such, apolitical) guide to action which available knowledge does not in fact warrant. Even if the pandemic has been a victory of sorts for consequentialism, it has also provided an instructive case study of the problems with CBA in circumstances of great uncertainty.

Of course, this problem has been recognized before in other contexts, but defenders of CBA have tended to minimize its scope. For example, Cass Sunstein, who is an eager advocate of CBA, has written that cases where agencies "may be operating under circumstances of ignorance, in which they cannot specify either outcomes or probabilities" are "rare." ${ }^{19}$ If by this Sunstein meant cases where regulators are required to make a decision based on no information at all, then the phenomenon is indeed rare. But cases of significant uncertainty are quite common. For example, in debates in the United States over the death penalty, some have argued that empirical evidence shows it provides a powerful deterrent, and as such it "saves" many lives. Others, however, have shown how sensitive these findings are to small changes in the models. ${ }^{20}$ It takes only a slight change to them to find that the death penalty increases the prevalence of murder. ${ }^{21}$

18. Barbara H Fried, “The Limits of a Nonconsequentialist Approach to Torts" (2012) 18 Legal Theory 231 at 231.

19. Cass R Sunstein, "The Limits of Quantification” (2014) 102 Calif L Rev 1369 at 1380, 1386. But $c f$ Cass R Sunstein, Worst-Case Scenarios (Harvard University Press, 2007) at 163 ("at least a degree of uncertainty, in which probabilities cannot be assigned with specified bands, is not so rare").

20. See John J Donohue \& Justin Wolfers, "Uses and Abuses of Empirical Evidence in the Death Penalty Debate" (2005) 58 Stan L Rev 791 [Donohue \& Wolfers, "Uses"]; John J Donohue, III \& Justin Wolfers, "Estimating the Impact of the Death Penalty on Murder" (2009) 11 Am L \& Econ Rev 249.

21. See Donohue \& Wolfers, "Uses," supra note 20 at 825-26. Incidentally, one of the targets of this article was Sunstein, who relying on earlier empirical studies, has argued in support of the death penalty. See ibid at 825 . Another study, more pertinent for present purposes, has delved into the costs and benefits of a single environmental regulation, again showing some of the uncertainties involved, is Thomas O McGarity, "Professor Sunstein's Fuzzy Math" (2002) 90 Geo LJ 2341. 
The difficulties with evaluating the costs and benefits of lockdown policies in the context of the COVID-19 outbreak far outweigh the difficulties with assessing the deterrent effect of the death penalty. In the death penalty studies, the relevant data are available and the biggest difficulty is isolating the impact of the death penalty from other societal changes that influence the prevalence of murder. This is difficult enough, but it is nothing compared to the levels of uncertainty decision makers are facing in the present pandemic.

Starting with the benefits of the lockdown policies, the most obvious one is saved lives. To know just how many lives have been saved by shutdown policies, one needs to know how many would have died without them. This is difficult, as there are significant differences in estimates of the infection rate and the infection fatality rate of the SARS-CoV-2, the virus that causes COVID-19. For reasons that are as yet not entirely clear, these rates have been dramatically different for different countries, and often also for different regions within one country, or within one country at different times. Even something as seemingly simple as the number of people who died from the virus-supposedly a matter of mere counting-is not quite certain, even though such a number is crucial for being able to evaluate the infectiousness of the virus. Calculations based on excess mortality suggest COVID-19 may be more lethal than official mortality counts say; but excess mortality calculations themselves may be inaccurate, as they may reflect deaths of people deciding to forgo treatment for other conditions. ${ }^{22}$ If such a choice is the result of the lockdown policies, these deaths may be attributed not to the virus but to the governmental response to it. On all these matters, our knowledge constantly improves, but it must be remembered that significant uncertainty remains and that initial decisions on lockdown had to be made against far higher levels of uncertainty.

Some attempts to calculate the costs and benefits of the lockdown included only saved lives as a benefit. But though the most significant benefit, it is not the only one. Another significant benefit of non-infection due to isolation is the saving from avoided infections for those who recover. This, of course, was always a benefit, but it assumes greater relevance as time goes by since mortality rates for those infected seem to have gone down quite dramatically across all age groups. ${ }^{23}$ Whatever the reasons, this means that the benefits of lockdown are

22. See Denis Grady, “The Pandemic's Hidden Victims: Sick or Dying, but Not from the Virus," The New York Times (14 May 2020), online: <nytimes.com/2020/04/20/health/ treatment-delays-coronavirus.html>.

23. See Heidi Ledford, "Why Do COVID Death Rates Seem to Be Falling?," (2020) 587 Nature 190. 
lower, but it must be remembered that one of the reasons for this improvement is that those infected today often get to less overwhelmed hospitals, because of the institution of lockdown policies. Another reason is that those infected today have the benefit of better treatment protocols than those infected in the early months of the pandemic. Avoiding these often-costly treatments is still a significant benefit from non-infection, i.e. from lockdown. Avoided infections also prevent the potential economic effects of an infected person's inability to work, which may extend to others, even if not themselves infected but who need to isolate. (To be sure, the lockdown itself may limit one's ability to work, but workplace adjustments have at least partially addressed this; someone ill may not be able to work, and had there been no lockdown fewer of these alternatives may have been developed.)

Further benefits from non-infection for those who without lockdown would have become ill and recovered are even more difficult to assess at this point. Chief among them are the long-term health effects of the virus: What was initially thought to be a virulent respiratory disease is now coming to be seen as an illness that afflicts some patients' hearts, kidneys, and even their brains. ${ }^{24}$ How frequent these effects are among those who recover, how serious they are, and especially how long they last are all at this stage largely unknown and may not be fully known for years. In addition to the savings from avoided infections, on the side of the benefits one has to include the significant improvement in air quality in many cities, as well as the decline in traffic and other accidents (following a decline in economic activity). ${ }^{25}$ Though many of these changes are temporary, some of this benefit may prove long lasting: Lockdown policy have had a disruptive effects on many workplace practices, which some predict will outlast

24. See Ariana Eunjung Cha, "Coronavirus Autopsies: A Story of 38 Brains, 87 Lungs and 42 Hearts," The Washington Post (1 July 2020), online: <washingtonpost.com/health/2020/ 07/01/coronavirus-autopsies-findings>; Pam Belluck, "Here's What Recovery from Covid-19 Looks Like for Many Survivors," The New York Times (1 July 2020), online: <nytimes. com/2020/07/01/health/coronavirus-recovery-survivors.html>; Ed Yong, "Long-Haulers Are Redefining covid-19," The Atlantic (19 August 2020), online: <theatlantic.com/health/ archive/2020/08/long-haulers-covid-19-recognition-support-groups-symptoms/615382/>.

25. See Farhad Manjoo, "I have Seen the Future Without Cars, and It's Amazing," The New York Times (9 July 2020), online: <nytimes.com/2020/07/09/opinion/sunday/ ban-cars-manhattan-cities.html>; Anne Case \& Angus Deaton, Deaths of Despair and the Future of Capitalism (Princeton University Press, 2020) at 26, 141-42 (mortality rates go down during recessions). 
the pandemic. ${ }^{26}$ If fewer people commute daily to work, if there is less business travel, one consequence of the pandemic may be long-term improvement in the environment.

On the side of costs, the most evident and immediate effect of the lockdown has been a massive economic slowdown. Unemployment in Canada jumped from 5.6 per cent prior to the pandemic to 13.7 per cent in May 2020 with entire industries (hospitality, entertainment, brick-and-mortar retail, among others) coming to an almost complete stop in activity. Though the government has been providing support for small businesses, it did not fully offset the losses, and data begin to suggest rise in bankruptcies, with the worst yet to come. ${ }^{27}$ Longer term effects of the lockdown policies are less clear, but past experience suggests that major economic shocks have long-term effects on the employment and earning prospects of those who are entering the labour market during (or in the aftermath of) the shock. ${ }^{28}$ In addition, there have already been reports of higher incidence of domestic abuse, mental health problems, and suicide as a result of the economic dislocation, isolation, and confinement following the shutdown policies. ${ }^{29}$ (To add to the complexity, to accurately measure the effect of government isolation policies, one has to exclude from the calculation behavioural changes that would have happened spontaneously.)

Another likely cost from the current crisis involves the significant debts governments incur to deal with increased expenditures and reduced revenue. In all likelihood these debts will be paid off, at least in part, from future budget

26. See Clive Thompson, "What If Work from Home Goes On...Forever?," The New York Times (9 June 2020), online: <nytimes.com/interactive/2020/06/09/magazine/ remote-work-covid.html>.

27. See Pete Evans, "As Covid-19 Relief Programs Wind Down, Bankruptcies Are Starting to Spike Again," CBC (15 November 2020), online: <cbc.ca/news/business/ insolvency-bankruptcy-covid-1.5798319>; see also Pat Foran, "More than Half of Canadian Restaurants May Close Permanently Within Months, Survey Finds," CTV News (28 August 2020), online: <toronto.ctvnews.ca/more-than-half-of-canadian-restaurants-may-closepermanently-within-months-survey-finds-1.5083961>.

28. See Eduardo Porter \& David Yaffe-Bellany, "Facing Adulthood with an Economic Disaster's Lasting Scars," The New York Times (19 May 2020), online: <nytimes.com/2020/05/19/ business/economy/coronavirus-young-old.html>.

29. See Jennifer Koshan, Janet Mosher \& Wanda Wiegers, "COVID-19, the Shadow Pandemic, and Access to Justice for Survivors of Domestic Violence" (2020) 57 Osgoode Hall LJ 739; see also Sebastian Payne, "Coronavirus: The Hidden Health Costs of the UK Lockdown," The Financial Times (26 April 2020), online: <ft.com/content/0ccaac50-854c-11eab555-37a289098206>; Cec Haire, "Increase in Domestic Violence Calls Persists Throughout the Pandemic, Says Non-Profit," CBC News (2 July 2020), online: <cbc.ca/news/canada/ newfoundland-labrador/violence-prevention-east-val-barter-domestic-covid-1.5632993>. 
cuts to various governmental programs. If history is our guide, it is safe to assume that such cuts will disproportionately hurt low-income individuals. To the extent that distributive considerations are relevant for $\mathrm{CBA}$ - and there are good reasons to think that they do-this is another likely cost of current policies, but whose magnitude it is very difficult at this stage to estimate.

With the effects of the shutdown discussed so far, one could place them on the side of costs or benefits with relative confidence. For other possible effects of the current pandemic, beyond estimating what will happen, it is difficult to know their overall valence. For instance, the lockdown policies forced many workplaces to switch quickly to remote work. This generated many immediate costs, but those may spur long-needed, beneficial changes to work practices. ${ }^{30}$ Several employers have indicated that they now plan to expand work-from-home practices, citing savings related to the acquisition and maintenance of expensive real estate and, more surprisingly, increased productivity. If such changes prove lasting, would the positives (e.g., more leisure time and less anxiety from avoided commutes to work, less pollution from reduced traffic) outweigh the negatives (e.g., less sociability)?

In assessing the costs and benefits of the pandemic, one significant unknown is the time it will take before life returns to something resembling its pre-pandemic form. This partly depends on how long it will take to develop a vaccine or an effective treatment for the virus. While the distribution of vaccines has begun, it will be months before they are widely available. Worryingly, there are also discouraging indications that a vaccine may provide only temporary or limited protection. In these circumstances, even small changes can have significant effects on our ability to return to engaging in the same social interactions known from before the pandemic. By then, some changes initially thought to be temporary may become permanent.

Even more significant changes may come about as a result of the pandemic, but these are even more difficult to predict and assess. Historians have argued that some pandemics have brought with them epoch-making change: The bubonic plague that killed between one-third to one-half of Europe's population in the middle of the fourteenth century is cited as an important factor in bringing about the end of feudalism, the beginning of the Renaissance and the emergence of capitalism; the 1918 pandemic is sometimes mentioned as bolstering the case for expanding the franchise to women. Closer to lawyers' concern, the very

30. For the suggestion that the court system may take advantage of pandemic to effect significant reform see Suzanne E Chiodo, "Ontario Civil Justice Reform in the Wake of COVID-19: Inspired or Institutionalized?” (2020) 57 Osgoode Hall LJ 801. 
justification for government regulation of public health that many now take for granted may have been born in reaction to the Black Death. In a book dedicated to the social effects of pandemics, Frank Snowden wrote that "[p]lague regulations ... cast a long shadow over political history. They marked a vast extension of state power into spheres of human life that had never before been subject to political authority.... The campaign against plague ... promoted an accretion of the power and legitimation of the modern state." ${ }^{31}$

It is possible that the current pandemic will have a similar impact. Before the pandemic, there were serious concerns over the vast amounts of personal data now held by tech companies and governments. In many countries the pandemic has led to the adoption of privacy-intruding policies, now possible with the use of digital technologies. Will people be willing to cast aside their worries over privacy for the sake of public health and a return to "normal life"? A news report on China noted that its government has "long sought to harness vast troves of digital information to their sprawling, sometimes unruly nation more efficiently." 32 Following the adage that one should not let a crisis go to waste, will China and other countries take advantage of this pandemic to expand the reach of such policies? If such changes do happen, should they be included in a CBA of the effects of government policies? And if so, how?33

\section{B. MODELS AND THEIR LIMITS}

Scientists face uncertainty all the time. This does not mean that they cannot make successful predictions. Their main tool for dealing with uncertainty is models. Models are tools for better understanding reality by way of creating a simplified representations of it. ${ }^{34}$ At times, the point of the simplification is to highlight certain aspects of reality, at others it is to make explanations and predictions more tractable, at still others it is to deal with gaps in available data. Therefore, that a

31. Frank M Snowden, Epidemics and Society: From the Black Death to the Present (Yale University Press, 2019) at 81-82; see also Mitchell L Hammond, Epidemics and the Modern World (University of Toronto Press, 2020) at 38-39.

32. See Raymond Zhong, "China's Virus Apps May Outlast the Outbreak, Stirring Privacy Fears," The New York Times (26 May 2020), online: <nytimes.com/2020/05/26/technology/ china-coronavirus-surveillance.html>.

33. One could be even more speculative: Before the outbreak, many forecasters predicted President Donald Trump would win re-election because the US economy was doing well. Trump's disastrous response to the pandemic and its effect on the American economy are now seen as one of the factors that have led to his loss. Should one count this as a benefit of the pandemic?

34. This in itself is a simplification, as models sometimes serve other functions. For a discussion see Tarja Knuuttila, "Models, Representation, and Mediation" (2004) 72 Phil Sci 1260. 
model leaves out certain aspects of reality-i.e., that strictly speaking, it is falseis not necessarily a problem with it.

By the same token, it is not enough to say that simply because scientists use models, uncertainty is not an issue. Not all models, and not all uncertainties, are created equal. ${ }^{35}$ In the present context, early models have reached widely divergent conclusions on the wisdom of various policies. ${ }^{36}$ For example, a group of economists concluded that lockdown policies were justified by comparing the value of saved lives with the economic costs of such policies and concluded that the former outweighs the latter: The estimated savings from the lockdown policies were valued at 12.4 trillion USD, which was deemed much greater than the estimated GDP losses to the United States economy, estimated at 7.21 trillion USD. ${ }^{37}$ As the model only calculated the benefits from saved lives against the cost as measured by decline in GDP, it excluded many of the costs and benefits mentioned above. By contrast, an epidemiologist, questioned lockdown policies by arguing that they were rushed and possibly inflated the harm caused by the illness (i.e., the benefits from government policies)..$^{38}$

Some of the differences related to questions of model design (e.g., what costs and benefits are included in the calculation) and empirical questions (e.g., how many people will die in the absence of lockdown policies), which are matters on which we can expect models to improve as better data are available, some of

35. Cf Daniel A Farber, "Modeling Climate Change and Its Impacts: Law, Policy, and Science" (2008) 86 Tex L Rev 1655 (explaining why climate models predicting global warming are superior to economic models of the economic impact of climate change).

36. See Martin Enserink \& Kai Kupferschmidt, "Mathematics of Life and Death: How Disease Models Shape National Shutdowns and Other Pandemic Policies," Science (25 March 2020), online: <sciencemag.org/news/2020/03/mathematics-life-and-deathhow-disease-models-shape-national-shutdowns-and-other>; Fareed Zakaria, "Why the Coronavirus Models Aren't Totally Accurate," The Washington Post (9 April 2020), online: <washingtonpost.com/opinions/without-mass-testing-were-flying-blind-throughthis-crisis/2020/04/09/bf61e178-7a9b-11ea-a130-df573469f094_story.html>; Joel Achenbach, “'Tell Me What to Do! Please!': Even Experts Struggle with Coronavirus Unknowns," The Washington Post (26 May 2020), online: <washingtonpost.com/health/ tell-me-what-to-do-please-even-experts-struggle-with-coronavirus-unknowns/2020/05/25/ e11f9870-9d08-11ea-ad09-8da7ec214672_story.html>.

37. See Linda Thunström et al, "The Benefits and Costs of Using Social Distancing to Flatten the Curve for COVID-19" (2020) 11 J Benefit-Cost Analysis 179. The calculation for the benefit was an estimate of 1.24 million lives saved times 10 million USD per saved statistical life.

38. John PA Ioannidis, "A Fiasco in the Making? As the Coronavirus Pandemic Takes Hold, We Are Making Decisions Without Reliable Data," Stat (17 March 2020), online: <www. statnews.com/2020/03/17/a-fiasco-in-the-making-as-the-coronavirus-pandemic-takes-holdwe-are-making-decisions-without-reliable-data>. 
the differences are due to normative judgments. Here is one: what is the benefit accrued from a saved life? Setting aside ethical qualms about any attempt to answer such a question in terms of dollars and cents, one finds in the relevant literature two different approaches that in the context of the COVID-19 pandemic may lead to very different conclusions. One approach uses the measure of "value of statistical life" (VSL) to measure the value of each life saved. Though there is no uniform measure for VSL, it is currently typically measured at about nine to ten million US dollars. The other approach, known as "Quality Adjusted Life Years" (QALY), measures how many years a regulatory intervention will add, and further weighs "healthy" years more than others. ${ }^{39}$ The latter approach thus treats the benefits from saving the life of an older person as lower than that of a young person, as the former has fewer years left to live, and those are typically of "lower" quality.

People of all age groups have died of COVID-19, but the distribution of fatalities has been very heavily skewed toward older people: In Canada, 96 per cent of those who died of COVID-19 were sixty years old or older. ${ }^{40}$ In addition, those who died tended to be people with several comorbidities, i.e. people who even before the outbreak were less healthy. ${ }^{41}$ One reason for the different conclusions of the two studies mentioned above is that the former used the VSL approach, whereas the latter took the age and health of most decedents into

39. These are not the only ones. For a discussion of these approaches and a proposal of yet another one see Sean Hannon Williams, "Statistical Children” (2013) 30 Yale J on Reg 63 (arguing for VSL with an added "child premium"). The text ignores many complications related to these two competing approaches. On some of them see Sunstein, supra note 5 at ch 3 .

40. See Sharon Kirbey, "In Canada, the Cases of COVID-19 and Deaths are Declining. Here's the Story Behind the Numbers," National Post (11 July 2020), online: <nationalpost. $\mathrm{com} /$ news/in-canada-the-cases-of-covid-19-and-deaths-are-declining-heres-the-storybehind-the-numbers $>$.

41. Eighty-one per cent of deaths from COVID-19 in Canada were of long-term care residents. See Canadian Institute of Health Information, Pandemic Experience in the Long-Term Care Sector: How Does Canada Compare with Other Countries? (June 2020) at 2, online (pdf): CIHI Snapshot <www.cihi.ca/sites/default/files/document/covid-19-rapid-response-longterm-care-snapshot-en.pdf >. According to a 2015 report, the average length of stay at a long-term care facility in Ontario was 2.7 years (the median was 1.6 years). See Health Analytics Branch, Ministry of Health and Long-Term Care, Long-Term Care in Ontario: Sector Review (September 2015) at 17, online (pdf): <longtermcareinquiry.ca/wp-content/ uploads/Exhibit-169-Long-Term-Care-in-Ontario-Sector-overview.pdf>. While these figures do not account for the reason for the end of the stay, the two most common reasons for discharge are a move to a hospital (46.9 percent) and death (30.6 per cent). See ibid at 16. 
account. ${ }^{42}$ Nothing in the CBA method itself answers the question which of these approaches should be adopted, and our practices do not reveal a perfectly consistent pattern. In some contexts, societies adopt something closer to the QALY approach: When it comes to allocating organs for transplantation to potential recipients, decision protocols give priority to younger and otherwise healthier patients. At other times, we reject such calculations and refuse comparisons that suggest some lives are worth more than others.

This point reveals a fundamental question about CBA that I have so far ignored, namely that despite its proponents' occasional claims to being engaged in a purely "technocratic" calculation, it contains unavoidable normative questions. Just how significant this component is, how devastating it is for CBA, is itself a (politically) contested question. I do not know of anyone who denies that some of the questions at the heart of CBA are not purely a matter of empirical calculation. To critics of CBA, this undermines the entire aspiration of employing CBA as a more rigorous (albeit potentially mistaken) method for assessing risk regulation. They contend that CBA is just better at hiding its normative choices under a veneer of false objectivity that comes with quantification. ${ }^{43}$ When this veneer is scratched off, it becomes evident that many quantifications that go into actual CBA rest on dubious foundations that lack scientific basis. ${ }^{44}$

Proponents of CBA acknowledge this and offer two responses. One is that there is still a meaningful distinction between scientific and normative questions; and they further argue that scientists should be in charge of the former. They point out that a major reason why risk regulation is so wasteful and irrational is

42. This in itself may reflect a disciplinary difference. VSL is common among economists, QALY among health care professionals. See Williams, supra note 39 at 120 . Thunström et al, supra note 37 , is the work of economists; Ioannides, supra note 38 , was written by a medical doctor and epidemiologist.

43. See Wendy E Wagner, "The Science Charade in Toxic Risk Regulation” (1995) 95 Colum L Rev 1613 at 1632-35, 1701-702; see also Cory Coglianese \& Gary E Merchant, "Shifting Sands: The Limits of Science in Setting Risk Standards" (2004) 152 U Pa L Rev 1255 at $1265,1274,1324$.

44. For demonstrations of the non-scientific, and often politically-motivated, assumptions that have gone into specific exercises in evaluating the costs and benefits of particular regulations see McGarity, supra note 21 at 2356-65; Mark Kelman, "On Democracy-Bashing: A Skeptical Look at the Theoretical and 'Empirical' Practice of the Public Choice Movement" (1988) 74 Va L Rev 199 at 239-60. 
because it is often driven by unfounded popular fears. ${ }^{45}$ For example, no matter how we measure the value of life, it is a matter of fact that terrorism poses a far smaller risk of death than heart attacks, and that budgetary outlays should reflect this fact, even if most people fear the former more.

For some, however, this view amounts to undermining democracy: What risks should be regulated and to what degree are political questions "all the way down." If people care or fear some risks more than others, their choices should be respected. Those who advance these views note that public attitudes about these matters are typically correlated with standard political worldviews or ideologies: for example, people with more egalitarians views tend to be more worried about global warming; people with more hierarchical views tend to be more concerned about drugs and want them to be more heavily regulated. ${ }^{46}$ To make risk experts decide how much to spend on different risks is to remove from democratic debate questions that have always been considered the core of public discourse. Indeed, for some of these defenders of regulatory democracy, the presentation of popular opinions on risk as "errors" is itself mistaken. People's attitudes to risk reflect certain identifiable patterns. For instance, the risk of a single event (a "disaster") leading to thousand deaths is considered worse than a similar risk leading to a similar number of deaths, when those are scattered over time; deaths perceived as involuntary or in circumstances of lack of control are perceived as worse than deaths in more "voluntary" circumstances; and "dread factor" makes some kinds of death (e.g., from a nuclear accident) be considered worse than others. For some, this does not show that people are irrational, but that, as psychologist Paul Slovic put it, people's "conceptualization of risk is much richer than that of the experts and reflects legitimate concerns that are typically omitted from expert risk assessments." ${ }^{47}$

This approach has led some to challenge the expert-led approach to risk regulation as fundamentally anti-democratic. But the argument is overdrawn. There are truths about risks, and usually experts know those better than most people. In making policy decisions on COVID-19, epidemiologists' views on

45. See e.g. Stephen Breyer, Breaking the Vicious Circle: Toward Effective Risk Regulation (Harvard University Press, 1993) at 59-63; Cass R Sunstein, Laws of Fear: Beyond the Precautionary Principle (Cambridge University Press, 2005) at 126-28. This view also assumes, controversially, that experts are better than lay people at insulating themselves from cognitive biases. I cannot deal with this question here.

46. See e.g. Dan M Kahan et al, "Fear of Democracy: A Cultural Evaluation of Sunstein on Risk" (2006) 119 Harv L Rev 1071 at 1083-87.

47. Paul Slovic, "Perception of Risk" (1987) 236 Sci 280 at 285. For drawing out the regulatory implications of this view see Kahan et al, supra note 46. 
the risks involved should count more than the views of peddlers of conspiracy theories. ${ }^{48}$ This is in fact a familiar feature of modern democracy. What percentage of the defence budget should be allocated for jet fighters as opposed to submarines, tanks, or cyberwarfare, is not a question decided by "the people," nor is it typically decided by their representatives; it is a question decided by experts. The same is true of most public health decisions, such as whether to purchase another fMRI machine or to hire more doctors (at the hospital level), or how much to allocate to education for healthier eating over cancer research (at the health-care system level). The reason is simple: Most people know nothing, or less than nothing, about these matters. The amount of misinformation about COVID-19 has been significant, with numerous unfounded claims about its origins, its risks, or of reliable methods for dealing with it. For all its uncertainty, scientific expertise on matters of public health is not just "one perspective" that is no better than any other, and there is already quite clear evidence that those places that followed well-established public health procedures have done better than those that have not. ${ }^{49}$

It is true, however, that the scope of decisions allocated to experts is itself a politically contested question, and one on which different countries take different approaches, reflecting different ways of subjecting CBA to democracy. Against this, a second response to the democratic deficit of CBA works by expanding what is included in the technocratic calculation of costs and benefits, thereby turning at least some normative questions into empirical ones. In a way, this approach tries to calculate democracy into the CBA. The democratic approach to risk regulation considered earlier, treats regulatory decisions based on fear as valid even if the fear is not grounded in facts, as long as the fear reflects people's genuine choices. By contrast, the technocratic response contends that an accurate calculation of costs and benefits must include the welfare costs that come from fear. ${ }^{50} \mathrm{~A}$ regulatory decision that will mitigate fear will generate benefits even

48. Those are more common than one would like to think. See Dominik Stecula, Mark Pickup \& Clifton van der Linden, "A Survey of Canadians Shows a Worrying Number of Believers More Likely to Ignore Recommended Health Behaviours. The Consequences Could Be Devastating," Policy Options (6 July 2020), online: <policyoptions.irpp.org/magazines/ july-2020/who-believes-in-covid-19-conspiracies-and-why-it-matters> (reporting on a poll that found that as many as 25 per cent of Canadians have some belief in at least one conspiracy theory about covid-19).

49. See e.g. Charles Duhigg, "Seattle’s Leaders Let Scientists Take the Lead. New York's Did Not," The New Yorker (26 April 2020), online: <newyorker.com/magazine/2020/05/04/ seattles-leaders-let-scientists-take-the-lead-new-yorks-did-not>.

50. See Matthew D Adler, "Fear Assessment: Cost-Benefit Analysis and the Pricing of Fear and Anxiety” (2004) 79 Chi-Kent L Rev 977. 
if the fear itself has no basis in reality. If accepted, it is difficult to limit this idea to one emotion. One's disappointment from the lack of protection for what one values is a cost that should be included: The opponent of abortion suffers a welfare loss from knowing that abortions are being legally performed; and the opponent of animal farming suffers a loss from knowing it is allowed, even if she is a vegetarian. Sunstein, who in the past favoured allocating risk regulation decisions to experts because they are better informed than the people, has more recently also argued that upset over such disappointed beliefs should be included in CBA. ${ }^{51}$

While the attempt to minimize the scope of politics in CBA may be admirable, this proposal is problematic. If this is to be done, many of the popular errors to be excluded from CBA will be brought back in into the calculation, only in different guise: People's erroneous views should not determine which risks to regulate; that remains a matter for experts. But experts will now be required to also include the costs accruing from people's disappointments of their errors not becoming law. In other words, whereas the "democratic" approach extends the domain of politics when it comes to who should make the decision, the expert-led "technocratic" approach may end up looking quite similar if it includes political preferences in determining what the costs and benefits are. ${ }^{52}$ It is odd to propose $\mathrm{CBA}$ as a means of avoiding errors in regulatory decisions, only to bring those errors back into the fold in a different way.

Furthermore, rather than improving CBA, such suggestions will make CBA calculations even more difficult to calculate, and consequently make the CBA process much more prone to political manipulation, a technique that could be used to justify any desired decision. Measurement problems are likely to be considerable, especially if we try to separate disappointed moral attitudes from factual errors, since in such matters empirical and normative beliefs are going to be deeply intertwined: Those who believe that some crimes deserve capital punishment (and therefore disappointed by its absence), will also tend to believe empirical evidence showing that it deters; those who believe that vaccinations cause autism will typically also hold the moral view that vaccination is a personal

51. Compare Sunstein, supra note 45 at 126 with Sunstein, supra note 5 at 108-10.

52. An even greater difficulty of separating the two arises if we classify (some) deontological moral attitudes as cognitive biases. Should these be ignored in technocratic CBA? CfDan Priel, "Do Societies Prioritize Harm Prevention?" (2019) 37 Revus 127 at 140-44. 
choice that is beyond the legitimate power of the state to mandate. ${ }^{53}$ Indeed, a challenge to a mistaken factual belief (vaccinations are dangerous) may adversely affect individual welfare no less than a challenge to a moral belief (vaccinations are a matter of personal choice).

The current pandemic illustrates this problem of separating factual errors from moral beliefs, and further shows how the factual uncertainty discussed in the previous section exacerbates it. The greater is the factual uncertainty, the more likely are factual estimates to be driven by_and perhaps also be presented as-moral beliefs. Anecdotal evidence suggests that those who believe that the risk of the virus is small tend also to think that masks do not prevent the spread of the virus (even though the two beliefs are completely independent of each other), and also hold the moral view that the state cannot force individuals to wear masks. ${ }^{54}$ Even if we dismiss their factual views as erroneous, they may come back into the calculation in the form of their moral beliefs.

To conclude, politics may enter CBA in at least three places: when deciding a questions like how to measure the value of life; when disappointed political beliefs are taken into account in determining the costs of a regulation; and when in circumstances of factual uncertainty political attitudes fill the gaps. Given the levels of uncertainty surrounding COVID-19, especially when the decisions on lockdown and shutdown were taken, the prospects of a reliable CBA are dim.

53. Cf Jeremy D Fraiberg \& Michael J Trebilcock, "Risk Regulation: Technocratic and Democratic Tools for Regulatory Reform” (1998) 43 McGill LJ 835 at 849-57. For psychological studies illustrating the point mentioned in the text in experimental settings see Charles G Lord, Less Ross \& Mark R Lepper, "Biased Assimilation and Attitude Polarization: The Effects of Prior Theories on Subsequently Considered Evidence" (1979) 37 J Personality \& Soc Psychol 2098 (balanced evidence on the deterrent effect of capital punishment was seen by both opponents and proponents as supporting their views and strengthened both sides' convictions); Peter H Ditto \& David F Lopez, "Motivated Skepticism: Use of Differential Decision Criteria for Preferred and Nonpreferred Conclusions" (1992) 63 J Personality \& Soc Psychol 568. To make things worse, studies suggest that once beliefs are formed, they tend to resist disconfirming information. See Lee Ross, Mark R Lepper \& Michael Hubbard, "Perseverance in Self-Perception and Social Perception: Biased Attributional Processes in the Debriefing Paradigm" (1975) 32 J Personality \& Soc Psychol 880.

54. Cf Gaëlle Marinthe et al, "Looking Out for Myself: Exploring the Relationship Between Conspiracy Mentality, Perceived Personal Risk, and COVID-19 Prevention Measures" (2020) 25 Brit J Health Psychol 957. This kind of motivated reasoning is found in other contexts. See Melissa Finucane et al, "The Affect Heuristic in Judgments of Risks and Benefits" (2000) 13 J Behav Decision Making 1 (finding a negative correlation between perceived risk of an activity and perceived benefit). 


\section{THREE STRATEGIES AND THE INESCAPABILITY OF POLITICS}

With scientific modelling proving inconclusive, different countries settled on different approaches. In a sufficiently fine-grained comparison, each country has tackled the problems arising from the pandemic somewhat differently; but zooming out from the details, we can identify several distinct approaches. One approach focused on significant lockdown of the entire population and the shutting down of many businesses as means for reducing the opportunities for infection and thus the spread of the virus. A second approach has attempted to continue with life as we know it on the assumption that in the long run this approach will achieve similar epidemiological results but at a lower cost. A third approach has focused on a very high volume of testing and tracing as a way of quickly identifying and isolating those infected..$^{55}$

In a loose sense we can think of these three approaches as models, ideal-types that the actual approaches taken by different countries may resemble more or less closely. All three models are broadly welfarist in orientation, and all assume the state has a significant role to play in protecting individuals from various health risks. My aim is not to call winners and losers. At the time of writing, many countries are still struggling to contain the spread of the virus, in some cases after declaring early victory only to face rising number of infections a few weeks later. By contrast, some countries have seen very small number of infections for reasons that are still not entirely clear. ${ }^{56}$ My aim instead is to show how the different approaches reflect awareness of the need to weigh costs against benefits, but how difficult it is to adopt a purely expert-led approach, especially when uncertainty is high.

Using very broad strokes, it is not difficult to present them in terms of CBA with the impact of different decisions on health, economic activity, and privacy

55. These are not the only strategies. Another approach was adopted in New Zealand, which effectively shut its borders. On this strategy see Michael G Baker et al, "New Zealand's Elimination Strategy for the covid-19 Pandemic and What Is Required to Make It Work" (2020) 133:1512 NZ Med J 10. This strategy has so far proven successful in New Zealand, but as the authors note, it is one that is easier to implement in an island country. Another country I will largely leave out of the following discussion is the United States. Though in some respects it is closest to the first strategy, it raises additional issues I cannot consider here.

56. See Hannah Beech, "No One Knows What Thailand Is Doing Right, but So Far, It's Working," The New York Times (16 July 2020), online: <nytimes.com/2020/07/16/world/ asia/coronavirus-thailand-photos.html> (Thailand, Vietnam, Myanmar, Cambodia, and Laos all reporting very low rates of infection). 
assessed differently. But this kind of "impressionistic CBA" can justify just about any conclusion. As the discussion above stressed the influence of politics on CBA, I will attempt to put the three strategies within a political framework. One of the upshots of this perspective is highlighting the limitations of the familiar single-axis spectrum of left (pro-regulation) versus right (anti-regulation) as the basis for analyzing the politics of risk regulation, as the different approaches considered do not easily map onto it. Nor do the different models map neatly on a spectrum of more or less democratic regimes: versions of the third strategy, for instance, have been adopted by both.

1. Lockdown: Most western democracies have adopted shutdown as their primary risk reduction strategy. In Canada, for example, it was around mid March that in short order the different provinces declared a state of emergency, which included orders for schools and many businesses to shut down, and that the federal government severely restricted entry into the country. ${ }^{57}$ In addition, in countries that adopted this approach, people were encouraged, and at times required, to stay at home, to practice social distancing, and wear personal protective equipment when outside. The stated rationale for this approach has been "flattening the curve." While the phrase suggests just slowing the number of cases while leaving the total number of infections similar (the flattened curve is also wider), such policies are likely to lead to lower mortality: Spreading the number of infections makes it easier for hospitals to manage new cases without being overwhelmed; it also gives health practitioners the opportunity to learn from experience and improve their treatment protocols so that those infected later receive better care.

Though the prolonged lockdown comes with heavy costs, including the intrusion into certain rights, this approach reflects relatively high concern for privacy, which in turn reflects a more-or-less conscious decision in the countries that opted for this approach to forgo potentially better ways of tracking the spread of the virus. I therefore call this approach "high security, high privacy." This approach is definitely not libertarian-it mobilizes the power of the state to actively promote and enforce health and economic security-but it still sought to maintains some limits on government action because of concern for individual rights.

While this approach is respectful of certain rights, it is hard to see them functioning as "trumps" over general welfare: Rights do not give individuals the power to act (let alone the power to force the state to protect the act) even if the

57. See Lauren Vogel, "COVID-19: A Timeline of Canada’s First-Wave Response," CMAJ News (12 June 2020), online: <cmajnews.com/2020/06/12/coronavirus-1095847>. 
action undermines welfare or is deemed by a majority to be undesirable. Rather, this approach suggests a possible alternative understanding of rights: Rights here serve as means for restricting government action that might otherwise pass CBA by giving weight to considerations that are difficult to quantify and as such likely to be ignored in more quantitative CBA. Conceptualized in this way rights can be seen as consistent with CBA, and perhaps even as a way of improving CBA in circumstances of great uncertainty. However, it must be admitted that without more, this approach can result in a highly imprecise and easily manipulable CBA. It is unclear how much weight should rights be given within an otherwise quantitative calculation of costs and benefits.

2. Natural herd immunity: A second approach tried to ride the outbreak in the hope of achieving natural herd immunity more quickly. This was the approach initially adopted in the United Kingdom, which changed course when mortality numbers began climbing at alarming rates, and in Sweden, which persisted for a longer period, until it too somewhat changed course. Though officially denied, this approach countenances a fairly large number of deaths early in the outbreak for the sake of maintaining a functioning economy as well as achieving herd immunity relatively quickly. ${ }^{58}$ (Swedish officials claimed in April 2020 their country would likely reach that goal in a matter of weeks, ${ }^{59}$ but later evidence did not support this claim. ${ }^{60}$ ) This approach did not call for "business as usual," as it encouraged individuals to change their behaviour. Nevertheless, in Sweden schools and businesses never shut down.

58. See Christina Anderson \& Henrik Pryser Libell, "In the Coronavirus Fight in Scandinavia, Sweden Stands Apart," The New York Times (28 March 2020), online: <nytimes. com/2020/03/28/world/europe/sweden-coronavirus.html>; Catherine Edwards, “Coronavirus: Will Sweden Ever Have a Total Lockdown?” The Local se (20 April 2020), online: <thelocal.se/20200420/coronavirus-will-sweden-ever-have-a-total-lockdown>.

59. See Kim Hjelmgaard, "Swedish Official Anders Tegnell Says 'Herd Immunity' in Sweden Might Be a Few Weeks Away,” USA Today (28 April 2020), online: <usatoday. com/story/news/world/2020/04/28/coronavirus-covid-19-sweden-anders-tegnell-herdimmunity/3031536001> (interview with the chief epidemiologist at Sweden's Public Health Agency).

60. See Maddy Savage, "Did Sweden's Coronavirus Strategy Succeed or Fail?," BBC News (24 July 2020), online: <bbc.com/news/world-europe-53498133>; Anne Grietje Franssen, "What Does Sweden's Lower-than-Expected Immunity Mean for the Future of Its Strategy," The Local se (20 November 2020), online: <thelocal.se/20201120/ what-does-swedens-lower-than-expected-immunity-mean-for-the-future-of-its-strategy> . 
Many are now looking at Sweden as an example of a misguided, even callous, approach. ${ }^{61}$ They point out that Sweden suffered far higher fatality rates than neighbouring Scandinavian countries that adopted strict lockdown policies, while still going through a fairly similar economic downturn. At the same time, Sweden has not been the worst-performing country in Europe. Its economy has indeed slowed down, although not as badly some European countries. (This in itself is not surprising if shutdown policies in other countries lead to a global slump in demand, which is likely to affect an export-led economy like Sweden's.) While some Swedish officials and economists still insist that the different policies should be evaluated at the end of the crisis, others have more recently begun questioning the wisdom of this approach. ${ }^{62}$

I am not in a position to address the epidemiological question, but it is worth remembering that even if it turns out to have been wrong in the end, that we should not evaluate it with the wisdom of hindsight. From the perspective of the early months of the pandemic, this approach might be explained as follows: Given the time it would take to develop a vaccine for the virus, it is unsustainable to maintain a shutdown that will last over a year. If that is the case, then the question is not whether the negative outcomes will happen, only when. In that case, getting the pandemic over with relatively early while building some kind of herd immunity through infection while keeping the economy open may look like a rational response. It is, however, a risky response, both in tolerating high mortality rates early on, as well as in adopting a strategy so out of step with almost all other countries. For a risk-averse politician there is safety in numbers in being able to point to a policy adopted throughout the world.

Thus, politically this approach is interesting not because it reflects a fundamentally different ideology from the first approach. (There is a certain irony in how "socialist" Sweden became almost overnight the darling of libertarians the world over.) No less than the first approach, the Swedish approach is grounded in a welfairst attitude that recognizes the role of state in maintaining public health, and with that role the inevitability of weighing costs against benefits. Instead, this approach highlights a different political factor, the willingness of the Swedish

61. See Paulina Neuding \& Tino Sanandaji, "Is Sweden's Lax Approach to the Coronavirus Backfiring?," The Washington Post (8 April 2020), online: <washingtonpost.com/ opinions/2020/04/08/is-swedens-lax-approach-coronavirus-backfiring>; cf Timms, supra note 13 at 40 (without mentioning Sweden, criticizing a herd immunity strategy as "eliminationist").

62. See Savage, supra note 60; Charlie Duxbury, "Sweden Split on Coronavirus Immunity," Politico (24 July 2020), online: <politico.com/news/2020/07/24/ sweden-catches-first-glimpse-of-herd-immunity-381117>. 
public to trust public health experts to take a leading role in policy making, even when it came to questions on which science could not provide clear answers. (Seen this way, Sweden no longer sounds like the libertarian's utopia.) Swedish society has long exhibited "collectivity, homogeneity, and consensualism," which together with its high levels of trust in government, explain this deferential attitude when faced with scientific uncertainty. ${ }^{63}$ This is one way of dealing with major gaps in the data needed for CBA, but it is an approach that is hard to export to places whose political culture is different.

3. Closer surveillance: Several countries adopted lockdown policies to which they added various tracking and surveillance mechanisms as a way of controlling the spread of the virus. To give a flavour of these approaches, "[i]n Singapore, the details of where patients live, work and play are released quickly online, allowing others to protect themselves." ${ }^{64}$ Similar practices were adopted in South Korea, where in addition, a new law "allows South Korean health officials to access a wide range of personal data, including cellphone location information and credit card transactions, without a court order." ${ }^{65}$

In many ways this model is similar to the first one, but it differs from it in being a "high security, low privacy" model. So far, this model seems to have been successful, and countries that adopted it (which along with South Korea include China and Taiwan) have been able to contain the spread of the virus with a relatively low infection and fatality rates. There are different possible reasons for this, including the fact that many of the countries adopting this model have

63. Jon Pierre, "Nudges Against Pandemics: Sweden's COVID-19 Containment Strategy in Perspective" (2020) 39 Pol'y \& Soc'y 478 at 480, 488, 489; Richard Milne, "Anders Tegnell and the Swedish Experiment," The Financial Times (10 September 2020), online: <ft.com/ content/5cc92d45-fbdb-43b7-9c66-26501693a371>.

64. Hannah Beech, "Tracking the Coronavirus: How Crowded Asian Cities Tackled an Epidemic," The New York Times (17 March 2020), online: <nytimes.com/2020/03/17/ world/asia/coronavirus-singapore-hong-kong-taiwan.html>; see also Cheryl Lu-Lien Tan, "Inside a Two-Week Quarantine in Singapore," The Washington Post (3 April 2020), online: <washingtonpost.com/opinions/2020/04/03/inside-two-week-quarantine-singapore>. For similar practices in South Korea see Mark Zastrow, "South Korea Is Reporting Intimate Details of COVID-19 Cases: Has It Helped?,” Nature (18 March 2020), online: <nature. com/articles/d41586-020-00740-y>.

65. Hyonhee Shin, Hyunjoo Jin \& Josh Smith, "How South Korea Turned an Urban Planning System into a Virus Tracking Database," Reuters (22 May 2020), online: <reuters.com/article/ us-health-coronavirus-southkorea-tracing/how-south-korea-turned-an-urban-planningsystem-into-a-virus-tracking-database-idUSKBN22Y03I>; see also See Natasha Singer \& Choe Sang-Hun, "As Coronavirus Surveillance Escalates, Personal Privacy Plummets," The New York Times (23 March 2020), online: <nytimes.com/2020/03/23/technology/ coronavirus-surveillance-tracking-privacy.html>. 
had a relatively recent experience with smaller epidemics, which made both the government and the population better prepared to respond quickly to the current outbreak. ${ }^{66}$ However, it seems that part of the difference in approach may also have something to do with a different political orientation. Specifically, this approach may reflect greater willingness of people to give up some of their rights for the sake of the common good. ${ }^{67}$ Indeed, some news reports from countries that adopted this strategy described popular efforts to enforce security measures that went even beyond government-mandated policies. ${ }^{68}$

\section{WHERE DO WE GO FROM HERE: THE WELFARE STATE AND INFORMATION}

It would be too facile to say that the three models described in the previous Part are straightforward application of CBA and just reflect different weights assigned to the costs and benefits due to uncertainty. To say this would render CBA consistent with virtually any policy. So understood, it will confirm what critics of CBA say of it, that for all its aspirations for rationality and apolitical objectivity, it is nothing more than a rhetorical device for giving political decisions the patina of neutral science. But the three approaches do show how political considerations affect the question of tradeoffs that CBA attempts to address. ${ }^{69}$ They can help guide thinking about risk regulation in cases of lower levels of uncertainty. One thing that the current situation highlights is the difficulty of incorporating CBA into a political process. As shown, one approach seeks to do so by turning political

66. Eun A Jo, "A Democratic Response to Coronavirus: Lessons from South Korea," The Diplomat (30 March 2020), online: <thediplomat. com/2020/03/a-democratic-response-to-coronavirus-lessons-from-south-korea>.

67. For examples and discussion of such attitudes from long before the pandemic see Daniel A Bell, Beyond Liberal Democracy: Political Thinking for an East Asian Context (Princeton University Press, 2006) at 73-75.

68. See Raymond Zhong \& Paul Mozur, "To Tame Coronavirus, Mao-Style Social Control Blankets China," The New York Times (15 February 2020), online: <nytimes. com/2020/02/15/business/china-coronavirus-lockdown.html> (reporting on a combination of government- and community-led efforts to restrict movement); Jo, supra note 66 ("It is the voluntary cooperation of the citizens that allowed the government to eschew more extreme measures and maintain a delicate balance between public safety and civil liberties. ... South Korea's 'democratic' response is ... a result of public solidarity.").

69. See Max S Kim, "Seoul's Radical Experiment in Digital Contact Tracing," The New Yorker (17 April 2020), online: <newyorker.com/news/news-desk/seouls-radical-experiment-indigital-contact-tracing ("few countries were getting away with not sacrificing some kinds of freedom. As [law professor] Kim [Min-ho] point out, the true question was which freedoms to prioritize"). 
attitudes into elements within the CBA calculus. I hinted (at best) at a different approach, one that retains the consequentialist core of CBA but recognizes the need to incorporate it within a political system.

I will conclude by briefly mentioning one example, which touches on one question that gets frequently asked these days: What will be the long-term effects of the pandemic? This question can, of course, be the subject of whole books. The one aspect of it I will consider here is the effects the shutdown policies will have on the role of the state. The three models I considered in the previous Part fit a broad definition a "welfare states," by which I mean states that take an active role in managing and reducing a wide range of risks that individuals face. This definition does not cover everything that states do, but it is not idiosyncratic either. It is based on the idea that a major role of the state is provide, or manage the provision of, security. In this sense there is continuity between the nineteenth-century night-watchman state as a provider of security against certain risks and the twentieth-century welfare state that provides security against a wider range of risks. ${ }^{70}$

Despite this continuity, it is also true that in the course of the twentieth century states "grew" in size compared to their nineteenth-century counterparts. One factor in this expansion in the role of the state came with the advent of new technologies, which made security against more risks possible. By "technologies," I mean human inventions, both physical (computing machines, tracking devices) and intellectual (statistics, probability), that made it possible to collect and analyze vast amounts of information. Much of what welfare states do requires, if it is to be done well, the deployment of these technologies. The great responsibilities that came with the assumption of great powers have created the information-hogging beast that is the welfare state. This beast-Hobbes called the state "Leviathan" for a reason —is both a (the) major provider of security and a (the) major source

70. CfStephen Holmes, Passions and Constraint: On the Theory of Liberal Democracy (University of Chicago Press, 1995) at ch 8 (arguing for continuity between classical liberalism and welfare). More specifically Holmes also shows that the association of freedom with security is not novel (see ibid at 245). See also Emma Rothschild, "What Is Security?" (1995) 124:3 Dædalus 53 at 61-63. What may have changed is the greater tendency to speak of this kind of government action as an enhancement of freedom rather than as an intrusion into it. See Lord Macmillan, Law \& Other Things (Cambridge University Press, 1937) at 8-9 ("I am not less but more the captain of my soul in a city which is well sewered, well paved, well policed, and free from slums and the diseases they breed, in which the education, the health and welfare of my fellow-citizens are promoted by sensible measures"); James M Landis, "Law and the New Liberties" (1939) 4 Mo L Rev 105 at 108; cf ER Hopkins, "Administrative Justice in Canada" (1939) 19 Can Bar Rev 619 at 626-27. 
of potential insecurity. The primary motivation for limiting government power is also a reason to want to strengthen it.

This is the paradox at the heart of the liberal welfare state: to be effective, it requires a lot of information about-and thus inevitably potential control over-individuals, all for the sake of maintaining security, which is in turn justified for promoting human independence. This is not an easy position to hold: Superficially, in their opposite ways, libertarians and authoritarians seem more consistent. The COVID-19 pandemic puts considerable strain on the welfare state, not just in the obvious sense of the enormous expenditures governments are currently incurring while simultaneously facing a significant shortfall in revenue. The pandemic also strains the welfare state in a deeper sense, in expanding state power, which inevitably brings with it greater risks to individual security, for the sake of greater security.

As shown above, some of the most successful countries in controlling the spread of COVID-19 have done so by adopting privacy-invasive policies. Various plans proposed for a return to normalcy in countries that followed the first model have almost invariably relied on implementing technological tools that in effect move them toward this model..$^{71}$ To anyone who accepts the logic of CBA, this approach could be justified as an acceptable response to an emergency: The use of intrusive technology has significant costs, which while not justified in normal times, could pass CBA muster during a pandemic. An emergency is a time of a heightened risk of a significant loss, the prevention of which justifies incurring greater costs. But history has shown that times of emergency (real or perceived) are rarely times of rational response; it has also shown that once granted,

71. See Ezra Klein, "I've Read the Plans to Reopen the Economy. They're Scary," Vox (10 April 2020), online: <vox.com/2020/4/10/21215494/coronavirus-plans-social-distancingeconomy-recession-depression-unemployment>; Gideon Lichfield, "We're Not Going Back to Normal," MIT Technology Review (17 March 2020), online: <technologyreview. com/2020/03/17/905264/coronavirus-pandemic-social-distancing-18-months >; Norimitsu Onishi \& Constant Méheut, "France Weighs Its Love of Liberty in Fight Against Coronavirus," The New York Times (17 April 2020), online: <nytimes.com/2020/04/17/ world/europe/coronavirus-france-digital-tracking.html>; Natasha Singer \& Choe Sang-Hun, "As Coronavirus Surveillance Escalates, Personal Privacy Plummets," The New York Times (17 April 2020), online: <nytimes.com/2020/03/23/technology/coronavirus-surveillancetracking-privacy.html>. 
"temporary" powers are often difficult to roll back. ${ }^{72}$ Would emergency measures adopted today become the new normal? ${ }^{73}$

This is an example of the way even those, like me, who are sympathetic to CBA must acknowledge that it is not a technocratic means of avoiding politics. Serious thinking about the way CBA is incorporated into politics will have to go beyond measuring the costs of those whose favoured moral or political views are disappointed. These issues and tensions existed, of course, before the pandemic. A year ago, a lot of public debate revolved around maintaining privacy in an age of ubiquitous digital technology. These debates are much subdued now, but one day we will go back to them. When that happens, the way they are reshaped by the pandemic may prove to be one of its most lasting effects.

72. Cf John Dryzek \& Robert E Goodin, "Risk-Sharing and Social Justice: The Motivational Foundations of the Post-War Welfare State" (1986) 16 Brit J Pol Sci 1 at 11-21 (showing how an expansion in government expenditure during World War II was not entirely rolled back after the war).

73. Cf Zhong, supra note 32 ("officials in some places [in China] are loading their [virus-tracking] apps with new features, hoping the software will live on as more than just an emergency measure"). 
